\title{
Syntheses of surfactants from oleochemical epoxides
}

Oléagineux, Corps Gras, Lipides. Volume 8, Numéro 1, 57-9, Janvier - Février 2001, Dossier : Deutsche Gesellschaft für Fettwissenschaft - Association française pour l'étude des corps gras

Auteur(s) : Siegfried WARWEL, Falk BRUSE, Herbert SCHIER, Mark RUSCH GEN. KLAAS, Berthold WIEGE, Federal Centre for Cereal, Potato and Lipid Research (BAGKF), Institute for Biochemistry and Technology of Lipids, H.P. Kaufmann-Institute, Piusallee 68, D-48147 Münster, Germany.

Résumé : Des surfactants d'hydrates de carbone peuvent être obtenus avec un bon rendement (jusqu'à $100 \%$ ) dans des conditions douces (à $70{ }^{\circ} \mathrm{C}$, dans du méthanol ou dans un mélange de méthanol et d'eau) par des réactions des époxydes avec des polyhydroxyalcoylamines. Des réactions de $\mathrm{N}$-méthylglucamine avec des oxydes d'alcoylènes supérieurs terminaux (C4-C18) ou des oxydes d'esters méthyliques d'acides gras à terminaisons insaturées amènent aux produits linéaires, tandis que des réactions avec de la $\mathrm{N}$-dodécylglucamine ou de la glucamine amènent aux surfactants avec des structures en $Y$ différentes. Les produits des réactions d'oxydes d'esters méthyliques d'acides gras à terminaisons insaturées subissent une saponification avec l'hydroxyde de sodium ou une hydrolyse enzymatique, ainsi on obtient respectivement des sels de sodium ou des acides, qui donnent des tensioactifs amphotères. L'étude des surfactants à différentes valeurs de $\mathrm{pH}$ montrent des propriétés tensioactives variées dans des solutions aqueuses. Pour quelques surfactants d'hydrates de carbone on trouve des petites c.m.c. (2-500 mg/l) et des tensions superficielles de 25 $40 \mathrm{mN} / \mathrm{m}$. Tandis que les produits de réactions des époxydes ont des pouvoirs moussants plutôt modérés, quelques bromohydrates correspondants ont de bonnes propriétés moussantes.

Mots-clés : époxydes, glucamines, surfactants.

Summary : Sugar-based surfactants were obtained in good yields (up to 100\%) under mild conditions $\left(70^{\circ} \mathrm{C}\right.$, methanol or mixtures of methanol and water) by ring-opening of terminal epoxides with aminopolyols, derived from glucose. Reaction of $\mathrm{N}$-methyl glucamine with epoxides from evennumbered C4-C18 alpha-olefins or from terminal unsaturated fatty acid methyl esters leads to linear products, while corresponding reactions with $\mathrm{N}$-dodecyl glucamine or glucamine yield surfactants with different Y-structures. Products obtained by conversion of omega-epoxy fatty acid methyl esters were saponificated with $\mathrm{NaOH}$ or hydrolyzed enzymatically to sodium salts or free acids respectively, which are amphoteric surfactants. Studies of the surfactants at different $\mathrm{pH}$-values demonstrate different surface active properties in aqueous solutions. Critical micelle concentrations (c.m.c.) in a range between 2 and $500 \mathrm{mg} / \mathrm{l}$ and surface tensions of $25-40 \mathrm{mN} / \mathrm{m}$ were measured for several of the synthesized sugar-based surfactants. The ring-opening products are rather poor foamers, whereas some of the corresponding hydrobromides show good foaming properties.

Keywords : epoxides, glucamines, surfactants. 


\section{ARTICLE}

Sugar based surfactants, such as alkyl polyglucosides, fatty acid N-methyl glucamides, sorbitan esters and sucrose esters gained importance in the last decade [1]. Further sugar-based surfactants are obtained by reaction of sugar-based amines, synthesized by reductive amination of reducing carbohydrates, with terminal epoxides. In contrast to ring opening of epoxides with alcohols, the reaction with amines takes place without catalysts. In the past these conversions were carried out at relatively high temperatures $\left(110-130^{\circ} \mathrm{C}\right)[2,3]$ or in solvents such as DMF [4, 5] or DMSO [6]. We have developed a new mild method $[7,8]$ and applied special terminal epoxides for this purpose.

\section{Starting materials}

As starting polyolamines for syntheses of surfactants different glucamines (glucamine, N-methyl glucamine, N-dodecyl glucamine) were used, which are industrially available from glucose by reductive amination using $\mathrm{NH}_{3}$, methyl amine or dodecyl amine, respectively (Figure 1).

These amines were used for the ring opening of epoxides, derived from alpha-olefins as well as from terminal unsaturated fatty acid methyl esters. The latter ones were obtained by metathesis of natural unsaturated fatty acid methyl esters with ethylene applying heterogeneous rhenium catalysts [9] or homogeneous ruthenium one-component-catalysts [10, 11]. Methyl esters from high-oleic sunflower oil or 00-rapseed oil lead to 9-decenoic acid methyl ester; starting with methyl esters from high-erucic rapeseed oil or crambe oil 13-tetradecanoic acid methyl ester was available. The terminal unsaturated $\mathrm{C}_{10^{-}}$and $\mathrm{C}_{14^{-}}$-esters as well as 10-undecenoic acid methyl ester, an industrial product from castor oil, were epoxidized applying a chemo-enzymatic method, which was developed in our laboratory on the base of pioneer work from Novo Nordisk [12]. Using Novozym ${ }^{\circ 435}$, the immobilized Lipase B from Candida antarctica, as catalyst methyl acetate was converted by $\mathrm{H}_{2} \mathrm{O}_{2}$ into peracetic acid, which in situ epoxidized the $\mathrm{C}=\mathrm{C}$-double bond [13-17]. The same method was utilized for the epoxidation of several alpha-olefins (Figure 2).

Beside the $\mathrm{C}_{10^{-}}, \mathrm{C}_{11^{-}}$and $\mathrm{C}_{14^{-}}$-epoxy fatty acid methyl esters even-numbered alpha-epoxides in the range from $\mathrm{C}_{4}$ to $\mathrm{C}_{18}$ were used for the synthesis of surfactants.

\section{Ring-opening reactions of epoxides with glucamines}

We could demonstrate, that in comparison with other methods, methanol or methanol/water mixtures as solvents and a temperature of $70^{\circ} \mathrm{C}$ are favorable reaction conditions for the epoxide ring opening. Depending on the glucamines used, reaction products of different structures were obtained (Figure 3). Starting from $\mathrm{N}$-methyl glucamine, surfactants with a linear structure were produced. $\mathrm{N}$ dodecyl glucamine led to a Y-type structure with two different hydrophobic alkyl chains, whereas reactions of glucamine with epoxides resulted in surfactants with Y-type structure having two identical hydrophobic chains. The products based on omega-epoxy fatty acid methyl esters and glucamine are dicarboxylic acid esters, which could be possibly polycondensed with diols or diamines. 
Product isolation was quite convenient and many products were obtained as white powders in fair yields (Table). The products were characterized by NMR, FT-IR and MALDI-TOF-MS. No ring-opening with hydroxyl groups was observed. Gel permeation chromatography (GPC) was applied for the determination of the product purity and for kinetic measurements of the reactions. Furthermore, elementary analyses and determination of amine values of the products by titration [18] were carried out.

\section{Surface active properties}

Surface active properties of the products were studied by determination of the solubilities, measurements of surface tensions of aqueous solutions carried out with a Krüss (K12) tensiometer according to Lecomte du Noüy [19] and determination of foaming characteristics (foam capacity and stability) according to DIN 53902-1 [20].

Some of the products showed very low solubilities. The basic amino group enables an increase of the solubility and surface active properties by its transformation into the corresponding salts. This was achieved by mixing the solutions or suspensions of the products with hydrobromic acid. In the group of surfactants based on alpha-epoxides and $\mathrm{N}$-methyl glucamine, N-2-hydroxy dodecyl-N-methyl glucamine reduced the surface tension of an aqueous solution down to $27 \mathrm{mN} / \mathrm{m}$ at a c.m.c. of $68 \mathrm{mg} / \mathrm{l}$. The corresponding hydrobromide achieved a value of $24.9 \mathrm{mN} / \mathrm{m}$ while the solubility was increased from 600 to $79,000 \mathrm{mg} / \mathrm{l}$.

The hydrobromides of reaction products from alpha-epoxides with glucamine show a drastic increase of the solubility as well and reduce the surface tension to approx. $30 \mathrm{mN} / \mathrm{m}$. Analogous results were obtained with products based on alpha-epoxides and $\mathrm{N}$-dodecyl glucamine.

For the products based on omega-epoxy fatty acid methyl esters solubilities of $350-100,000 \mathrm{mg} / \mathrm{l}$, surface tensions of $31-45 \mathrm{mN} / \mathrm{m}$ and critical micelle concentrations of $30-1,700 \mathrm{mg} / \mathrm{l}$ illustrate their surface active properties.

The esters were converted to their sodium salts by saponification with sodium hydroxide and to the corresponding free carboxylic acids by enzymatic hydrolysis using Novozym ${ }^{\circ} 435$ as biocatalyst [8]. Owing to their acid and their amino groupe, amphoteric surfactants were obtained with solubilities of $800-30,000 \mathrm{mg} / \mathrm{l}$ and values for $\mathrm{g}$ of $37-48 \mathrm{mN} / \mathrm{m}$ for the acids and those with the corresponding values of $210,000-600,000 \mathrm{mg} / \mathrm{l}$ and $26-40 \mathrm{mN} / \mathrm{m}$ for the salts.

The foaming properties of the epoxide ring-opening products are generally rather poor, with the exceptions of $\mathrm{N}$-2-hydroxydodecyl $\mathrm{N}$-methyl glucamine, the hydrobromides of $\mathrm{N}$-2-hydroxy tetradecyl N-methyl glucamine and of N,N-bis-(2-hydroxy decyl) glucamine as well as some others [7, 8].

Further investigations on the synthesis of surfactants based on carbohydrates and oleochemical epoxides are in progress in our laboratory. 


\section{REFERENCES}

1. HILL K, RHODE O (1999). Sugar-based surfactants for consumer products and technical applications. Fett/Lipid, 101: 25-33.

2. BEHLER A, BIERMANN M, DAUTE $P$, et al. (1992). Aminopolyole aus Ringöffnungen von Epoxiverbindungen mit Aminozuckern. Assigned to Henkel KGaA. German patent DE 4238214A1.

3. BEHLER A, BIERMANN M, DAUTE $P$, et al. (1992). Darstellung von Bissorbityl-aminopolyolen für Polymere (Polyurethan-Schäume). Assigned to Henkel KGaA. German patent DE 4238215A1.

4. ULSPERGER E (1962). Verfahren zur Herstellung von grenzflächenaktiven Polyhydroxyalkylaminen und deren Säureadditionssalzen. Assigned to Deutsche Akademie der Wissenschaften zu Berlin. German patent DAS 1220438.

5. ENGLER G (1965). Addition von n-Octylenoxid-(1,2) an Aminopolyalkohole zu nichtionogenen grenzflächenaktiven N-(2-Hydroxy-n-octyl)-polyhydroxyalkylaminen. PhD thesis, Humbold-Universität Berlin.

6. KRIER V, BASSILANA C, MARTIN B, CAMBON A (1998). Synthesis and comparison of highly fluorinated, nonionic surfactants. Tenside Surf Det, 35: 160-4.

7. WARWEL S, RÜSCH GEN. KLASS M, SCHIER H, BRÜSE F, WIEGE B (2001). Surfactants from glucamines and alpha-epoxides. Tenside Surf Det, 38: 7-14.

8. WARWEL S, RÜSCH GEN. KLASS M, SCHIER H, BRÜSE F, WIEGE B (2001). Surfactants from glucamines and omega-epoxy fatty acid esters. Eur J Lipid Sci Techn (submitted).

9. WARWEL S, JÄGERS HG, THOMAS S (1992). Metathese ungesättigter Fettsäure-ester - ein einfacher Zugang zu langkettigen Dicarbonsäuren. Fat Sci Technol, 94: 323-8.

10. SCHWAB P, FRANCE MB, ZILLER JW, GRUBBS RH (1995). A Series of Well-Defined Metathesis Catalysis-Synthesis of $\left[\mathrm{RuCl}_{2}(=\mathrm{CHR})-\left(\mathrm{PR}_{3}\right)_{2}\right]$ and Its Reactions. Angew Chem, Int Ed Engl, 34: 2039-41.

11. WARWEL S, BRÜSE F, DEME SC, KUNZ M, RÜSCH GEN. KLASS M (2001). Polymers and surfactants on the basis of renewable resources. Chemosphere, 43: 39-48.

12. BJÖRKLING F, GODTFREDSEN SE, KIRK O (1990). Lipase-mediated formation of peroxy carboxylic acids used in catalytic epoxidation of alkenes. J Chem Soc Chem Commun Vol, 1301-3.

13. WARWEL S, RÜSCH GEN. KLASS M (1995). Chemo-enzymatic epoxidation of unsaturated carboxylic acids. J Mol Catal, B1: 29-35.

14. RÜSCH GEN. KLASS M, WARWEL S (1997). Lipase-catalyzed preparation of peroxy acids and their use for epoxidation. J Mol Catal, A117: 311-9.

15. RÜSCH GEN. KLASS M, WARWEL S (1999). Chemoenzymatic epoxidation of alkylenes by dimethyl carbonate and hydrogen peroxide. Organic Lett, 1: 1025-6. 
16. WARWEL S, RÜSCH GEN. KLAAS M (2000). New peroxycarboxylic acids by lipase catalysis: preparation and oxidation properties. In: ADAM W, ed. Peroxide chemistry-mechanistic and preparative aspects of oxygen transfer. Wiley-VCH, Weinheim, Germany: 209-31.

17. RÜSCH GEN. KLAAS M, WARWEL S (2000). Lipase-catalyzed peroxy fatty acid generation and lipid oxidation. In: BORNSCHEUER UT, ed. Enzymes in lipid modification. Wiley-VCH, Weinheim, Germany: 116-27.

18. Total amine value of fatty amines and Primary, secondary, and tertiary amine values of fatty amines. In: FIRESTONE D, ed. Official methods and recommended practices of the Am Oil Chem Soc, forth edition. Tf 1a-64 and Tf 2a-64.

19. German industrial standard (1984). Bestimmung der Grenzflächenspannung, Bügel-oder Ringmethode, DIN 53993.

20. German industrial standard (1997). Bestimmung des Schäumvermögens, DIN 53902-1.

Illustrations

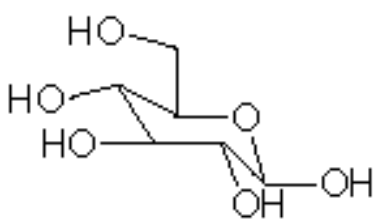

glucose

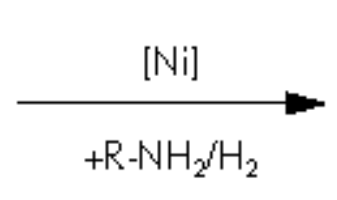

$\mathbf{R}=\mathrm{H}, \mathrm{CH}_{3}, \mathrm{C}_{12} \mathrm{H}_{25}$<smiles>[R]NCC(O)C(O)C(O)[C@H](O)CO</smiles> 


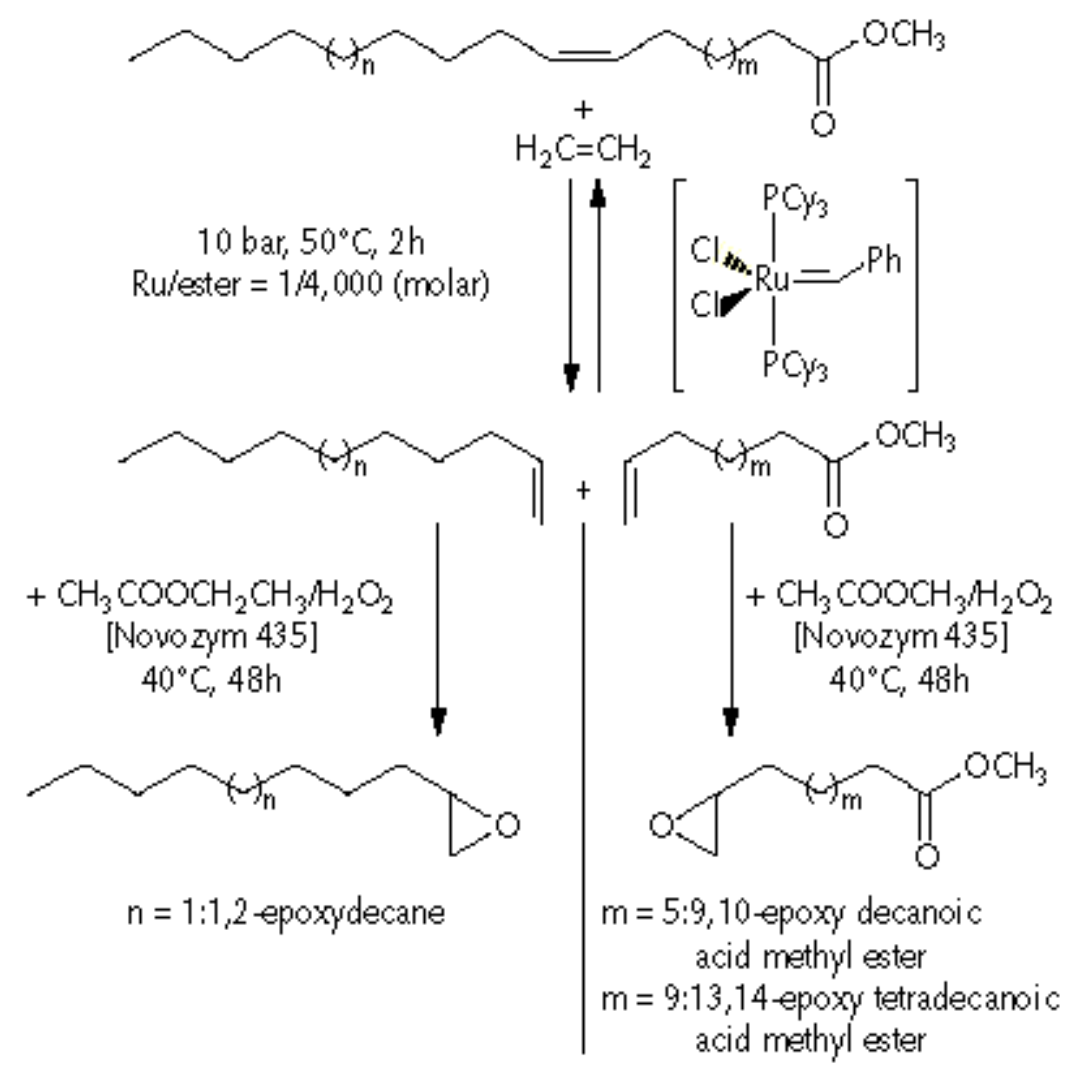

Figure 2. Synthesis of alpha-epoxides and terminal epoxy fatty acid methyl esters. 


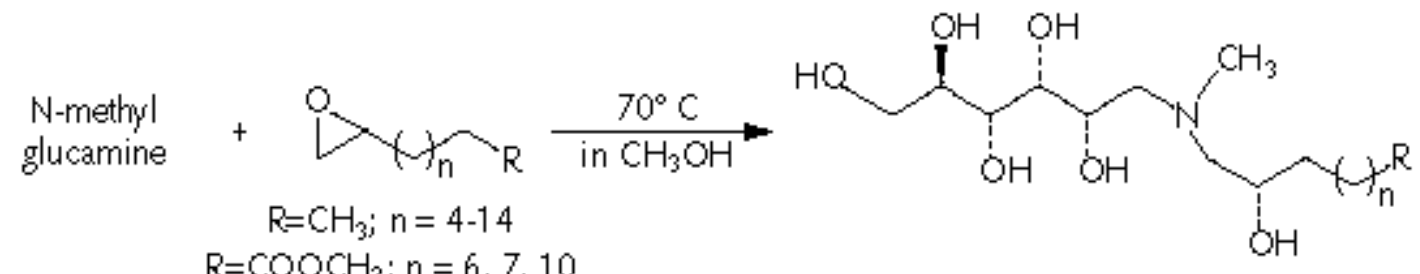

$\mathrm{R}=\mathrm{COOCH}_{3} ; n=6,7,10$

$N$-dodecyl glucamine

$+$<smiles>[R]CCC1CO1</smiles><smiles>C[C@H](O)[C@H](C)O</smiles>
$\mathrm{R}=\mathrm{CH}_{3} ; \mathrm{n}=0,4$

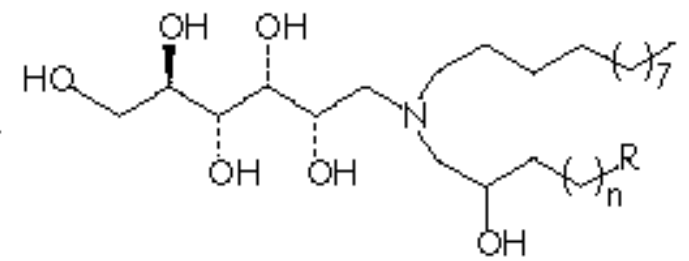

glucamine

$+2$<smiles>[R]CNC1CO1</smiles><smiles>O[14CH2][14CH2][14CH2][14CH2][14CH2]O</smiles>

$\mathrm{R}=\mathrm{CH}_{3} ; \mathrm{n}=0-14$ $\mathrm{R}=\mathrm{COOCH}_{3} ; n=6,7,10$<smiles>[R]CCC(O)CN(CC(O)C[R])CC(O)C(O)C(O)[C@H](O)CO</smiles>

Figure 3. Reactions of glucamines with terminal epoxides leading to surfactants with different structures.

Table. Ring-opening reactions of epo xides with glucamines.

\begin{tabular}{|c|c|c|c|c|}
\hline Amine & Epoxidea & $\mathbf{t}$ [h] & Yield [\%] & Purity [\%] ${ }^{\mathrm{D}}$ \\
\hline $\begin{array}{l}\mathrm{N} \text {-methyl } \\
\text { glucamine }\end{array}$ & $\begin{array}{c}C_{8}-C_{18} \\
C_{10} \div C_{11}=C_{14}-M E\end{array}$ & $\begin{array}{c}2-18 \\
24\end{array}$ & $\begin{array}{c}97-100 \\
99,26^{*}, 50^{*}\end{array}$ & $95-100$ \\
\hline $\begin{array}{l}\mathrm{N} \text {-dodecyl } \\
\text { glucamine }\end{array}$ & $\mathrm{C}_{4}, \mathrm{C}_{\mathrm{B}}$ & 10 & $70^{*}, 83^{*}$ & $94-100$ \\
\hline glucamine & $\begin{array}{c}C_{4}-C_{10} \\
C_{12}-C_{18} \\
C_{10}, C_{11}, C_{14}-M E\end{array}$ & $\begin{array}{c}10-48 \\
48 \\
5-18\end{array}$ & $\begin{array}{c}94-100 \\
90^{*}-98^{*} \\
64^{*}, 62^{*}, 72^{*}\end{array}$ & $92-100$ \\
\hline
\end{tabular}

Amine/epoxide = $1 / 1$ resp. $1 / 2$; methanol $/$ water $=5-100 / 0-1($ molar $) ; 70 \mathrm{C}$.

" Yield after aystallization from cold reaction solution or after adding acetone or diethyl ether. Without aystallization yiald are quantitative, with similar results for the purity.

"e.g. $C_{B}=1,2$ epoxyoctane, $C_{10}-M E=9,10$ epoxy decanoic acid methyl ester.

b Determined by GPC and messurement of amine values. 